\title{
Formation and occurrence of dimer esters of pinene oxidation products in atmospheric aerosols
}

\author{
K. Kristensen ${ }^{1}$, K. L. Enggrob ${ }^{1}$, S. M. King ${ }^{2, *}$, D. R. Worton ${ }^{3,4}$, S. M. Platt ${ }^{2, * *}$, R. Mortensen ${ }^{2, * * *}$, T. Rosenoern ${ }^{2, * * * *}$, \\ J. D. Surratt ${ }^{5}$, M. Bilde ${ }^{2, * * * * *}$, A. H. Goldstein ${ }^{3}$, and M. Glasius ${ }^{1}$ \\ ${ }^{1}$ Department of Chemistry and iNANO, Aarhus University, 8000 Aarhus C., Denmark \\ ${ }^{2}$ Department of Chemistry, University of Copenhagen, 2100 Copenhagen, Denmark \\ ${ }^{3}$ Department of Environmental Science, Policy and Management, University of California, Berkeley, CA 94720, USA \\ ${ }^{4}$ Aerosol Dynamics Inc., Berkeley, CA 94710, USA \\ ${ }^{5}$ Department of Environmental Sciences and Engineering, Gillings School of Global Public Health, University of North \\ Carolina at Chapel Hill, Chapel Hill, NC 27599, USA \\ *now at: Haldor Topsoe, 2800 Kongens Lyngby, Denmark \\ ** now at: Paul Scherrer Institute, 5243 Villigen PSI, Switzerland \\ *** now at: Umhvørvisstovan Environment Agency, 165ARGIR, Faroe Islands \\ **** now at: FORCE Technology, 2605 Brøndby, Denmark \\ ***** now at: Departmen of Chemistry, Aarhus University, 8000 Aarhus C, Denmark
}

Correspondence to: M. Glasius (marianne@glasius.dk)

Received: 13 July 2012 - Published in Atmos. Chem. Phys. Discuss.: 28 August 2012

Revised: 11 March 2013 - Accepted: 13 March 2013 - Published: 10 April 2013

\begin{abstract}
The formation of carboxylic acids and dimer esters from $\alpha$-pinene oxidation was investigated in a smog chamber and in ambient aerosol samples collected during the Biosphere Effects on Aerosols and Photochemistry Experiment (BEARPEX). Chamber experiments of $\alpha$-pinene ozonolysis in dry air and at low $\mathrm{NO}_{\mathrm{x}}$ concentrations demonstrated formation of two dimer esters, pinyl-diaterpenyl (MW 358) and pinonyl-pinyl dimer ester (MW 368), under both lowand high-temperature conditions. Concentration levels of the pinyl-diaterpenyl dimer ester were lower than the assumed first-generation oxidation products $\mathrm{cis}$-pinic and terpenylic acids, but similar to the second-generation oxidation products 3-methyl-1,2,3-butane tricarboxylic acid (MBTCA) and diaterpenylic acid acetate (DTAA). Dimer esters were observed within the first $30 \mathrm{~min}$, indicating rapid production simultaneous to their structural precursors. However, the sampling time resolution precluded conclusive evidence regarding formation from gas- or particle-phase processes. CCN activities of the particles formed in the smog chamber displayed a modest variation during the course of experiments, with $\kappa$ values in the range $0.06-0.09$ (derived at a supersaturation of $0.19 \%$ ).
\end{abstract}

The pinyl-diaterpenyl dimer ester was also observed in ambient aerosol samples collected above a ponderosa pine forest in the Sierra Nevada Mountains of California during two seasonally distinct field campaigns in September 2007 and July 2009. The pinonyl-pinyl ester was observed for the first time in ambient air during the 2009 campaign, and although present at much lower concentrations, it was correlated with the abundance of the pinyl-diaterpenyl ester, suggesting similarities in their formation. The maximum concentration of the pinyl-diaterpenyl ester was almost 10 times higher during the warmer 2009 campaign relative to 2007, while the concentration of cis-pinic acid was approximately the same during both periods, and lack of correlation with levels of cis-pinic and terpenylic acids for both campaigns indicate that the formation of the pinyl-diaterpenyl ester was not controlled by their ambient abundance. In 2009 the concentration of the pinyl-diaterpenyl ester was well correlated with the concentration of DTAA, a supposed precursor of diaterpenylic acid, suggesting that the formation of pinyl-diaterpenyl dimer was closely related to DTAA. Generally, the pinyl-diaterpenyl ester was found at higher concentrations under higher temperature conditions, both in the 
smog-chamber study and in ambient air aerosol samples, and exhibited much higher concentrations at night relative to daytime in line with previous results.

We conclude that analysis of pinyl dimer esters provides valuable information on pinene oxidation processes and should be included in studies of formation and photochemical aging of biogenic secondary organic aerosols, especially at high temperatures.

\section{Introduction}

Biogenic secondary organic aerosol (BSOA) is formed through atmospheric oxidation and processing of naturally emitted volatile organic compounds (VOC), and comprises a major fraction of secondary organic aerosols (SOA) in ambient air (Hallquist et al., 2009). Aerosols affect climate through light scattering and by influencing the formation and lifetime of clouds (IPCC, 2007; Lohmann and Feicher, 2005; Andreae and Rosenfeld, 2008). To evaluate the climatic impact of atmospheric aerosols, it is important to understand their chemical composition and sources as well as the chemical processes that form and transform them in the atmosphere.

Monoterpenes constitute an important group of biogenic VOC (BVOC) emitted from coniferous trees as well as other types of vegetation (Guenther et al., 1995). The atmospheric lifetime of monoterpenes is of the order of minutes to hours due to their fast reaction with hydroxyl radicals $(\mathrm{OH})$, nitrate radicals $\left(\mathrm{NO}_{3}\right)$ and ozone $\left(\mathrm{O}_{3}\right)$ (Atkinson and Arey, 1998; Calogirou et al., 1999). The first-generation oxidation products of monoterpenes constitute a complex group of primarily carbonyl compounds, carboxylic acids, and organic nitrates (e.g., Yu et al., 1999; Glasius et al., 2000; Larsen et al., 2001; Hallquist et al., 2009; Camredon et al., 2010; Perraud et al., 2010; Fry et al., 2009), which can undergo further atmospheric processing such as oxidation (e.g., Szmigielski et al., 2007; Müller et al., 2012), formation of organosulfates (e.g., Surratt et al., 2008; Iinuma et al., 2007) and oligomerization (e.g., Tolocka et al., 2004; Kalberer et al., 2004). These processes (whether homogenous or heterogeneous) can incorporate otherwise volatile or semi-volatile compounds into the particle phase as less volatile products (Kroll and Seinfeld, 2008; Jimenez et al., 2009; Hallquist et al., 2009). Formation of oligomers, including dimers, from $\alpha$-pinene ozonolysis products is an important SOA transformation process (e.g., Tolocka et al., 2004; Gao et al., 2004; Müller et al. 2008; Putman et al., 2012) that has been estimated to contribute as much as $50 \%$ to nonvolatile SOA mass (Hall IV and Johnston, 2011).

Dimers have often been identified according to their molecular weight determined by mass spectrometry, but based on previously proposed structures (Table 1) we suggest a more clear nomenclature where the names reflect the com- ponents of the dimer esters according to present understanding of their molecular structures. For example, the dimer of molecular weight (MW) 358 is called pinyl-diaterpenyl ester, the dimer of MW 344 is called diaterpenyl-terpenyl ester and the dimer of MW 368 is called pinonyl-pinyl ester, These three dimer esters have been recently observed in several smog-chamber studies of both $\alpha$ - and $\beta$-pinene oxidation (Müller et al., 2008, 2009; Camredon et al., 2010; Yasmeen et al., 2010; Gao et al. 2010).

Yasmeen et al. (2010) presented the first ambient measurements of the pinyl-diaterpenyl ester and diaterpenyl-terpenyl ester in particles collected during warm nights at K-Puszta, Hungary. However, it was unclear whether they were only detected during warm nights due to a temperature effect promoting ester formation at higher temperatures or due to photochemical degradation of the esters during daytime.

In this work we report concentrations and diurnal variations of first- and second-generation oxidation products of $\alpha$ - and $\beta$-pinene (listed in Table 1) in aerosol samples collected above a ponderosa pine plantation in California, USA, during the Biosphere Effects on Aerosols and Photochemistry Experiment (BEARPEX) 2007 and 2009. We investigated the influence of temperature on the formation of dimer esters and compared with results from dark smog-chamber ozonolysis of $\alpha$-pinene under cool $\left(15^{\circ} \mathrm{C}\right)$ and warm $(23-$ $24^{\circ} \mathrm{C}$ ) conditions.

\section{Experimental}

\subsection{Smog-chamber study}

Experiments were conducted at the University of Copenhagen using a smog-chamber setup consisting of a Teflon bag (Foiltech Gmbh) suspended from a metal frame in a temperature-controlled laboratory. The bag was shielded from light by dark curtains. Dimensions of the bag were $2.65 \mathrm{~m} \times 2.95 \mathrm{~m} \times 3.15 \mathrm{~m}(\mathrm{H} \times \mathrm{W} \times \mathrm{L})$, giving a volume of $\sim 25 \mathrm{~m}^{3}$ and a surface-area-to-volume ratio of $\sim 2 \mathrm{~m}^{-1}$. Stainless steel manifolds with inlet and outlet ports were mounted on two sides of the bag. All inlet and sampling lines reaching into the chamber were stainless steel. The temperature inside the bag was controlled by varying the temperature of the entire laboratory. $\mathrm{O}_{3}$ was measured using a Thermo Electron Corporation Model 49i $\mathrm{O}_{3}$ monitor, and oxides of nitrogen $\left(\mathrm{NO}_{\mathrm{x}}\right)$ were measured using a Thermo Electron Corporation Model 42i $\mathrm{NO}_{\mathrm{x}}$ monitor. Temperature and relative humidity $(\mathrm{RH})$ were measured inside the bag using a Rotronic Hygroclip HC2-C04 monitor. Initial $\mathrm{O}_{3}$ concentrations, temperature, and $\mathrm{RH}$ for each experiment are given in Table 2. $\mathrm{NO}_{\mathrm{x}}$ concentrations were $2 \mathrm{ppb}$ or below in all experiments. RH was less than $1 \%$.

All experiments were performed in the dark. Particle size distributions were measured using a scanning mobility particle sizer (SMPS) system (TSI SMPS model 3936L72 
Table 1. Overview of compounds investigated in this study. References: (1) Claeys et al. (2009); (2) Yasmeen et al. (2010); (3) Szmigielski et al. (2007).

\begin{tabular}{|c|c|c|c|}
\hline Compound (reference) & Suggested molecular structure & Molecular formula & {$[\mathrm{M}-\mathrm{H}]^{-}$ion $(\mathrm{m} / \mathrm{z})$} \\
\hline Pinonic acid & & $\mathrm{C}_{10} \mathrm{H}_{16} \mathrm{O}_{3}$ & 183.101 \\
\hline Hydroxy-pinonic acid & & $\mathrm{C}_{10} \mathrm{H}_{16} \mathrm{O}_{4}$ & 199.104 \\
\hline Pinic acid & & $\mathrm{C}_{9} \mathrm{H}_{14} \mathrm{O}_{4}$ & 185.080 \\
\hline Terpenylic acid ${ }^{1}$ & 0 & $\mathrm{C}_{8} \mathrm{H}_{12} \mathrm{O}_{4}$ & 171.065 \\
\hline Diaterpenylic acid ${ }^{2}$ & & $\mathrm{C}_{8} \mathrm{H}_{16} \mathrm{O}_{5}$ & 189.190 \\
\hline 3-Methyl-1,2,3-butanetricarboxylic acid ${ }^{3}$ (MBTCA) & & $\mathrm{C}_{8} \mathrm{H}_{12} \mathrm{O}_{6}$ & 203.055 \\
\hline Diaterpenylic acid acetate $^{1}$ (DTAA) & & $\mathrm{C}_{10} \mathrm{H}_{16} \mathrm{O}_{6}$ & 231.086 \\
\hline Pinyl-diaterpenylic ester ${ }^{2}$ MW 358 & & $\mathrm{C}_{17} \mathrm{H}_{26} \mathrm{O}_{8}$ & 357.156 \\
\hline Pinonyl-pinyl ester ${ }^{2}$ MW 368 & & $\mathrm{C}_{19} \mathrm{H}_{28} \mathrm{O}_{7}$ & 367.175 \\
\hline
\end{tabular}

Table 2. Summary of the experimental conditions in the smog chamber.

\begin{tabular}{lllll}
\hline Exp \# & $\begin{array}{l}\text { Date } \\
(\mathrm{d}-\mathrm{m}-\mathrm{y})\end{array}$ & $\begin{array}{l}{\left[\mathrm{O}_{3}\right]_{0}} \\
(\mathrm{ppb})\end{array}$ & $\begin{array}{l}{[\alpha \text {-pinene }]_{0}} \\
(\mathrm{ppb})\end{array}$ & $\begin{array}{l}T \\
\left({ }^{\circ} \mathrm{C}\right)\end{array}$ \\
\hline 1 & $20-07-2011$ & 116 & 100 & 23 \\
2 & $25-07-2011$ & 105 & 100 & 24 \\
3 & $28-07-2011$ & 116 & 100 & 15 \\
4 & $29-07-2011$ & 100 & 100 & 15 \\
\hline
\end{tabular}

consisting of a DMA model 3081 with a 3772 CPC operating with recirculating sheath air $\left(10: 1 \mathrm{~L} \mathrm{~min}^{-1}\right.$ sheath-toaerosol flow ratio). Size distributions $(7-300 \mathrm{~nm})$ were sampled every $3.5 \mathrm{~min}$. No $\mathrm{OH}$ scavenger or seed aerosol was added to the chamber in any of the experiments.

Aerosol samples were collected at $17 \mathrm{~L} \mathrm{~min}^{-1}$ for 15 or $30 \mathrm{~min}$ using 47-mm Teflon filters at chamber temperature. $\mathrm{O}_{3}$ was removed from the sample stream by passing the aerosol through a potassium iodide coated annular glass denuder (URG-2000-30B) prepared following Williams and
Grosjean (1990), and gas-phase organic compounds were removed in a similar manner using an XAD-4 coated glass denuder. The two denuders were placed in series in front of the filter. Filters were stored at $-18^{\circ} \mathrm{C}$ and under dark conditions until chemical analysis.

Prior to each experiment, the Teflon bag was cleaned; first it was flushed with $\mathrm{O}_{3}$ and air and left with a high concentration of $\mathrm{O}_{3}$ (ppm levels) for a couple of hours, and afterwards flushed with dry clean air until the $\mathrm{O}_{3}$ concentration was again below a few ppb. The chamber was then filled with high-pressure dried purified air, and $\mathrm{O}_{3}$ was added $\left(\mathrm{O}_{3}\right.$ Technology AB Model ACF-500) until an initial concentration around $100 \mathrm{ppb}$ was reached (actual values are given in Table 2). $16 \mu$ l of $\alpha$-pinene (Sigma Aldrich, $\geq 99 \%$ ) was added to the chamber by injection into a clean air stream $\left(10 \mathrm{~L} \mathrm{~min}^{-1}\right)$; this air stream was kept on for approximately 5 min to ensure proper mixing of the $\alpha$-pinene and $\mathrm{O}_{3}$. Further mixing in the bag was insured by pulses of high-pressure air into the bag. The initial concentration of $\alpha$-pinene was estimated to be approximately $100 \mathrm{ppb}$ based on the known 
volume of the chamber and the volume of $\alpha$-pinene added $\left(\mathrm{M}=136.23 \mathrm{~g} \mathrm{~mol}^{-1}, \rho=0.858 \mathrm{~g} \mathrm{~mL}^{-1}\right)$.

Cloud condensation nuclei $(\mathrm{CCN})$ activity of the particles formed in the chamber was measured using a continuousflow CCN counter (Droplet Measurement Technologies $\mathrm{CCN}-100)$. The size distribution of the particles were first narrowed to monodispersity with a TSI DMA model 3081 before the particles were simultaneously measured for activated number concentration by the $\mathrm{CCN}$ counter and for total number concentration by a TSI CPC model 3010 . Further details of the data acquisition methodology can be found in King et al. (2012). The temperature difference within the column of the CCN counter was set such that the supersaturation was $0.19 \%$. CCN activities were recorded for both experiments performed at $15^{\circ} \mathrm{C}$ (sample temperature of the CCN column was $23^{\circ} \mathrm{C}$, experiment 2) and at $24^{\circ} \mathrm{C}$ (sample temperature of the $\mathrm{CCN}$ column was $23^{\circ} \mathrm{C}$, experiment 3) for the entire course of the experiments. A fitting procedure was used to calculate activation diameters from measured activation curves, in which contributions from multiply charged particles were accounted for (Petters et al., 2007).

\subsection{Field study}

The BEARPEX campaign took place at a ponderosa pine (Pinus ponderosa L.) plantation owned by Sierra Pacific Industries adjacent to the University of California Blodgett Forest Research Station (UC-BFRS; $38.90^{\circ} \mathrm{N}, 120.63^{\circ} \mathrm{W}$, $1315 \mathrm{~m}$ elevation above sea level). High-volume filter samples (33 in total including two field blanks) were collected on $20 \mathrm{~cm} \times 25 \mathrm{~cm}$ quartz fiber filters (Gellman QM-A) at $9.3 \mathrm{~m}$ on the main tower from 20-25 September 2007 (16 samples) and 26-31 July 2009 (17 samples). The 2007 sampling period was during early fall, with colder temperatures $\left(11 \pm 5^{\circ} \mathrm{C}\right)$ than during the 2009 summer campaign $\left(25 \pm 4{ }^{\circ} \mathrm{C}\right.$, Table 3$)$.

Samples were collected using a Thermo Anderson Total Suspended Particulate (TSP) high-volume sampler with an SA-230-F impactor at a volumetric flow of $68 \mathrm{~m}^{3}$ hour $^{-1}$, as previously described by Bench and Herckes (2004). The impactor removed particles with diameters larger than $2.5 \mu \mathrm{m}$. The quartz filters were prefired by baking at $600{ }^{\circ} \mathrm{C}$ for $12 \mathrm{~h}$ and were stored in sealed foil-lined plastic bags prior to use. After sampling with the quartz filters, they were immediately placed in prebaked aluminum foil and stored frozen at $-18^{\circ} \mathrm{C}$ until analyzed. Field blanks were obtained by placing one filter in the sampler for ten minutes with the pump off around the midpoint of each sampling period. These filters represented two continuous five-day periods, one in each year, with three filters per day that provided an uninterrupted time series with sufficient time resolution to separate the influence of local early morning biogenic emissions from the afternoon arrival of the urban plume from Sacramento and nighttime chemistry. Aliquots $\left(115 \mathrm{~cm}^{2}\right)$ of these filters were used in this study.

\subsection{Extraction and analysis}

Filters from the 2007 campaign were analyzed 2 yr after collection, while filters from the 2009 campaign were analyzed after approximately $1 \mathrm{yr}$. All filter samples were extracted in acetonitrile in an ultrasonic bath. The filters were removed and the solvent evaporated under a gentle flow of nitrogen. The sample was then re-dissolved in $3 \%$ acetonitrile with $0.1 \%$ acetic acid in water and filtered using a $0.45 \mu \mathrm{m}$ Teflon syringe filter.

Samples were analyzed on a Dionex Ultimate HPLC equipped with a Waters T3 column $(2.1 \times 150 \mathrm{~mm}, 3 \mu \mathrm{m}$ particle diameter) coupled through an electrospray ionization (ESI) inlet to a Bruker microTOFq quadrupole timeof-flight mass spectrometer (qTOF-MS), as previously described (Kristensen and Glasius, 2011). The HPLC mobile phase was acetic acid $0.1 \%$ in water (v/v) (eluent A) and acetonitrile (eluent B) and a 50 min gradient elution was applied: eluent B was kept at $3 \%$ for $5 \mathrm{~min}$, increased to $90 \%$ in $25 \mathrm{~min}$, kept at $90 \%$ for $10 \mathrm{~min}$, then increased to $95 \%$ in $2 \mathrm{~min}$, held for $6 \mathrm{~min}$, and finally decreased to $3 \%$ in $5 \mathrm{~min}$. The injection volume was $10 \mu \mathrm{L}$ and the flow rate was $0.2 \mathrm{~mL} \mathrm{~min}^{-1}$. The ESI-qTOF was operated in the negative mode at the following conditions: nebulizer pressure 0.8 bar, dry gas flow $8.0 \mathrm{~L} \mathrm{~min}^{-1}$, source voltage $4 \mathrm{kV}$, collision gas argon, quadrupole ion energy $5.0 \mathrm{eV}$, collision cell energy $10.0 \mathrm{eV}$ and transfer time $100 \mathrm{~ms}$.

Samples were calibrated to authentic standards of the following acids: cis-pinic acid, pimelic acid (98\%), and cis-pinonic acid (98\%) (obtained from Sigma-Aldrich) and terpenylic acid, diaterpenylic acid acetate (DTAA), and 3methyl-butane tricarboxylic acid (MBTCA) (obtained from Y. Iinuma and O. Böge, Leibniz Institute for Tropospheric Research, Germany). Five-level calibration curves were constructed from 0.1 to $10.0 \mu \mathrm{g} \mathrm{mL}^{-1}$. Due to a lack of authentic standards, diaterpenylic acid was quantified using an average of the terpenylic acid and DTAA calibration curves and the concentration of the three dimer esters (pinyldiaterpenyl, diaterpenyl-terpenyl and pinonyl-pinyl) were determined from the average calibration curves of their precursors. Detection limits were $0.5-1.7$ ng injected (see Kristensen and Glasius, 2011 for details).

To rule out the possibility that dimer esters are formed during sample extraction and analysis, we performed a study of artifact formation of dimer esters. Solutions of suspected ester precursors (pinic acid, pinonic acid, terpenylic acid, MBTCA and DTAA, each about $10 \mu \mathrm{g} \mathrm{mL}^{-1}$ ) were left at room temperature or at $5^{\circ} \mathrm{C}$ for 4 days and analyzed. Very low concentrations of artifact dimer esters were observed. Since they have the same retention times as the acid precursors, these dimer ester are identified as artifacts formed in the MS system in contrast to aerosol dimer esters, which tend to have longer chromatographic retention times than their suggested precursors. 
Table 3. Average concentrations of pinene oxidation products, average relative humidity (RH) and temperature during BEARPEX 2007 and 2009. Standard deviations are shown in brackets.

\begin{tabular}{|c|c|c|c|c|c|c|c|c|}
\hline \multirow[t]{2}{*}{ Campaign year } & \multicolumn{4}{|c|}{2007 (“cold") } & \multicolumn{4}{|c|}{2009 ("hot") } \\
\hline & $\begin{array}{l}\text { Morning } \\
(n=5)\end{array}$ & $\begin{array}{l}\text { Afternoon } \\
(n=5)\end{array}$ & $\begin{array}{l}\text { Night } \\
(n=5)\end{array}$ & $\begin{array}{l}2007 \text { Average } \\
(n=15)\end{array}$ & $\begin{array}{l}\text { Morning } \\
(n=5)\end{array}$ & $\begin{array}{l}\text { Afternoon } \\
(n=5)\end{array}$ & $\begin{array}{l}\text { Night } \\
(n=5)\end{array}$ & $\begin{array}{l}2009 \text { Average } \\
(n=15)\end{array}$ \\
\hline Temperature $\left(\mathrm{C}^{\circ}\right)$ & $12.7( \pm 4.8)$ & $12.7( \pm 4.2)$ & $6.7( \pm 1.0)$ & $11( \pm 5.0)$ & $28.2( \pm 1.0)$ & $27.5( \pm 1.0)$ & $18.9( \pm 1.0)$ & $25( \pm 4.0)$ \\
\hline Relative humidity (\%) & $63( \pm 29)$ & $67( \pm 24)$ & $83( \pm 10)$ & $70( \pm 25)$ & $37( \pm 13)$ & $35( \pm 6)$ & $45( \pm 5)$ & $39( \pm 11)$ \\
\hline Organic aerosol $(\mathrm{OA})\left(\mu \mathrm{g} \mathrm{m}^{-3}\right)$ & $1.5( \pm 0.3)$ & $2.3( \pm 0.7)$ & $2.3( \pm 0.7)$ & $2.1( \pm 0.7)$ & $4.2( \pm 2.9)$ & $4.9( \pm 1.9)$ & $3.19( \pm 0.9)$ & $4.3( \pm 2.3)$ \\
\hline Pinonic acid $\left(\mathrm{ng} \mathrm{m}^{-3}\right)$ & $7.1( \pm 2.0)$ & $6.8( \pm 2.3)$ & $4.5( \pm 0.8)$ & $6.1( \pm 0.6)$ & $14.8( \pm 7.2)$ & $7.7( \pm 2.3)$ & $10.7( \pm 2.2)$ & $11.0( \pm 5.6)$ \\
\hline Pinic acid $\left(\mathrm{ng} \mathrm{m}^{-3}\right)$ & $6.3( \pm 3.6)$ & $7.6( \pm 4.7)$ & $9.0( \pm 2.6)$ & $7.6( \pm 4.0)$ & $8.3( \pm 3.4)$ & $4.8( \pm 1.9)$ & $8.4( \pm 1.2)$ & $7.1( \pm 3.0)$ \\
\hline Terpenylic acid $\left(\mathrm{ng} \mathrm{m}^{-3}\right)$ & $12.8( \pm 3.5)^{*}$ & $17.9( \pm 9.1)^{*}$ & $14.8( \pm 4.9)^{*}$ & $15.2( \pm 6.9)^{*}$ & $9.6( \pm 3.9)$ & $8.7( \pm 3.0)$ & $6.7( \pm 0.8)$ & $8.5( \pm 3.3)$ \\
\hline Diaterpenylic acid acetate (DTAA) $\left(\mathrm{ng} \mathrm{m}^{-3}\right)$ & $3.1( \pm 2.9)^{*}$ & $5.0( \pm 4.0)^{*}$ & $6.9( \pm 2.4)^{*}$ & $5.0( \pm 3.7)^{*}$ & $6.0( \pm 2.7)$ & $6.0( \pm 2.5)$ & $7.3( \pm 2.5)$ & $6.5( \pm 2.7)$ \\
\hline Diaterpenylic acid $\left(\mathrm{ng} \mathrm{m}^{-3}\right)$ & $0.4( \pm 0.4)^{* *}$ & $0.5( \pm 0.3)^{* *}$ & $0.8( \pm 0.4)^{* *}$ & $0.6( \pm 0.4)^{* *}$ & $1.2( \pm 0.8)^{* *}$ & $1.4( \pm 0.6)^{* *}$ & $0.8( \pm 0.4)^{* *}$ & $1.2( \pm 0.7)^{* *}$ \\
\hline MBTCA $\left(\mathrm{ng} \mathrm{m}^{-3}\right)$ & $3.3( \pm 5.0)^{*}$ & $2.0( \pm 2.5)^{*}$ & $8.8( \pm 10.2)^{*}$ & $4.7( \pm 7.6)^{*}$ & $7.2( \pm 5.6)$ & $8.7( \pm 4.5)$ & $10.8( \pm 3.1)$ & $8.9( \pm 4.9)$ \\
\hline Pinyl-diaterpenyl ester, MW $358\left(\mathrm{ng} \mathrm{m}^{-3}\right)$ & $0.1( \pm 0.1)^{* *}$ & $0.1( \pm 0.2)^{* *}$ & $0.4( \pm 0.1)^{* *}$ & $0.2( \pm 0.2)^{* *}$ & $3.3( \pm 1.6)^{* *}$ & $3.5( \pm 1.5)^{* *}$ & $4.2( \pm 0.7)^{* *}$ & $3.7( \pm 1.5)^{* *}$ \\
\hline Pinonyl-pinyl ester, MW $368\left(\mathrm{ng} \mathrm{m}^{-3}\right)$ & n.d. & n.d. & n.d. & n.d. & $0.3( \pm 0.2)^{* *}$ & $0.3( \pm 0.2)^{* *}$ & $0.4( \pm 0.1)^{* *}$ & $0.4( \pm 0.2)^{* *}$ \\
\hline
\end{tabular}

* Quantified using response factor due to lack of authentic standards.

** Quantified using surrogate standard due to lack of authentic standards - see experimental section for details. n.d: Not detected.

\section{Results and discussion}

\subsection{Smog-chamber experiments}

During the smog-chamber ozonolysis of $\alpha$-pinene (at low RH and low $\mathrm{NO}_{\mathrm{x}}$ ), two dimer esters were observed: the pinyldiaterpenyl ester (MW 358) composed of pinic acid and diaterpenylic acid units, and the pinonyl-pinyl ester (MW 368) composed of hydroxy-pinonic acid and pinic acid units. The supplemental information shows extracted ion chromatograms (EIC), MS and MS-MS spectra of these esters. The two esters were identified by their characteristic MSMS fragmentation pattern. The MS-MS fragmentation of the pinyl-diaterpenyl ester observed in this study resembles the fragmentation pattern described by Yasmeen et al. (2010).

Figure 1 shows concentrations of pinic acid, pinonic acid, hydroxy-pinonic acid, terpenylic acid, DTAA, MBTCA, pinonyl-pinyl ester and pinyl-diaterpenyl ester as a function of time during the experiments (normalized concentrations are shown in the Supplement, Fig. S3). In all cases the concentrations increase during the first $\sim 100-150 \mathrm{~min}$ and reach a maximum before decreasing towards the end of the experiments, similar to particle concentrations and most likely due to wall losses. Figure 2 shows the particle size and mass distributions of experiment 2 as a function of time (similar figures for experiments 1, 3, and 4 shown in the Supplement). The presented data have not been corrected for wall losses. Particle mass was obtained from SMPS data assuming spherical particles with an assumed SOA density of $1.23 \mathrm{~g} \mathrm{~cm}^{-3}$ based on previous work (Song et al., 2007).

The pinyl-diaterpenyl and pinonyl-pinyl esters were observed under both cold and warm conditions during the smog-chamber experiments, reaching concentrations comparable to several first- and second-generation oxidation products (i.e., the first-generation product pinonic acid, and the second-generation products DTAA and MBTCA, Fig. 1). The pinyl-diaterpenyl ester showed somewhat higher max- imum concentrations during the warm experiments (about $0.7 \mu \mathrm{g} \mathrm{m}^{-3}$ ) compared to the cold ones (about $0.4 \mu \mathrm{g} \mathrm{m}^{-3}$ ), while the pinonyl-pinyl ester showed no clear temperature dependency (maximum concentrations in the range 0.25$0.4 \mu \mathrm{g} \mathrm{m}^{-3}$ ). The concentration of pinonic acid is lower in warm experiments compared to cold, while pinic acid (also a first-generation oxidation product) tends to show the opposite behavior. The second generation product MBTCA shows higher particle-phase concentrations at higher temperatures. While the vapor pressure of the first-generation products are expected to increase with temperature (Bilde and Pandis, 2001), gas-particle partitioning is also regulated by chemical reactions in the gas or condensed phase. For example, higher $\mathrm{OH}$ concentrations at higher temperature results in increased oxidation of pinonic acid to MBTCA in the gas phase followed by condensation (as observed by Muller et al., 2012). The observations in Fig. 1 reflect the complexity of gas-particle partitioning, and we are not able to separate the temperature effect on vapor pressure from the effects of chemical reactions in the gas phase and condensed phase and condensed phase. Both dimer esters were observed within $30 \mathrm{~min}$ of addition of $\alpha$-pinene, indicating that they are formed within the same timeframe as the formation of their structural precursors, at our time resolution. Using online APCI-MS with high time resolution, Müller et al. (2008) observed that intensity of esters increased even faster than the intensity of their monomer precursors in freshly nucleated aerosol in the $\alpha$-pinene $/ \mathrm{O}_{3}$ system. The latter lead them to suggest that gas-phase ester formation could be important for homogeneous nucleation, although the reaction mechanism has not yet been elucidated. A gas-phase ester-forming mechanism could involve stabilized Criegee intermediates, formed by ozonolysis. The high $\mathrm{O}: \mathrm{C}$ ratio of esters $(0.47$ and 0.36, respectively) points towards Criegee intermediates since otherwise several oxidation steps would be needed to incorporate the high number of oxygen molecules, implying a slower process than monomer formation. Heaton et 

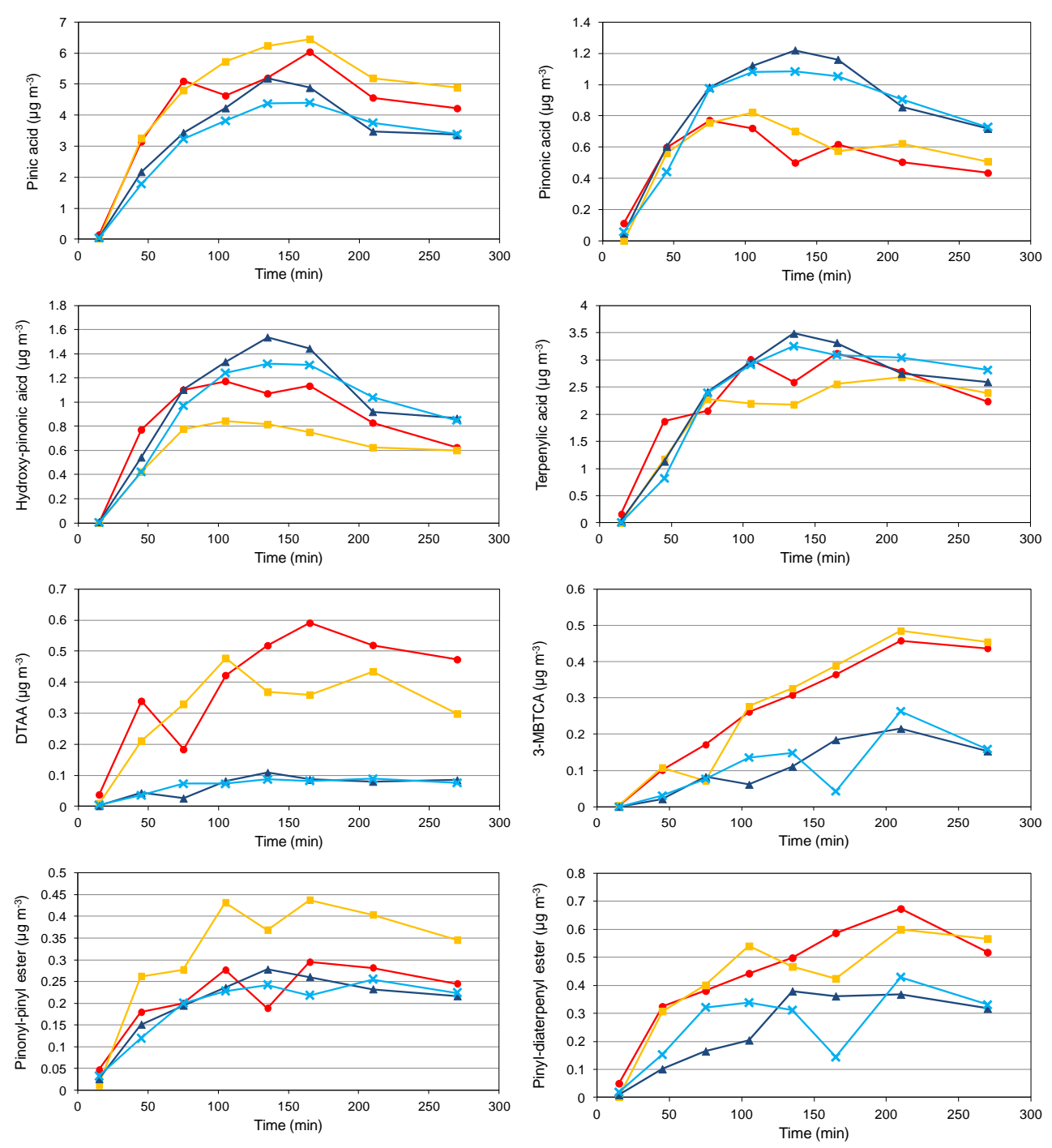

$\rightarrow-\operatorname{Exp} 1\left(23^{\circ} \mathrm{C}\right)-\operatorname{Exp} 2\left(24^{\circ} \mathrm{C}\right) \rightarrow \operatorname{Exp} 3\left(15^{\circ} \mathrm{C}\right) * \operatorname{Exp} 4\left(15^{\circ} \mathrm{C}\right)$

Fig. 1. Concentration profiles during smog-chamber experiments. No correction for wall losses has been applied.

al. (2007) observed almost immediate formation of dimers and higher order oligomers in a flow tube study of monoterpenes ozonolysis, indicating that ester formation had almost no kinetic barrier and likely consisted of very few oxidation steps. Gas-phase formation of pinyl-diaterpenyl and pinonyl-pinyl esters from Criegee intermediates would also explain why the esters were observed simultaneously with classical first-generation products such as cis-pinonic acid. However, we did not observe dimer esters in concentrations above the detection limit in extracts from the gas-phase denuder samples. The saturation vapor pressure of pinic acid $\left(9.5 \times 10^{-6} \mathrm{~Pa}\right.$ at $24^{\circ} \mathrm{C}$ and $3.8 \times 10^{-5} \mathrm{~Pa}$ at $15^{\circ} \mathrm{C}$ extrapolated from Bilde and Pandis (2001)) is significantly above the limit $\left(1.2 \times 10^{-8} \mathrm{~Pa}\right)$ for it to be a nucleating species (Bonn and Mortgat, 2003).
We estimated the vapor pressure of the pinyl-diaterpenyl and pinonyl-pinyl esters using the $\mathrm{p}^{0}$ calculator (Clegg et al., 2008) provided on the online Extended AIM Aerosol Thermodynamics Model homepage (http://www.aim.env.uea.ac. uk/aim/aim.php). Three structure-based estimation methods for boiling point and vapor pressure of pure liquid organic compounds are used: first, following Nannoolal et al. (2004) for boiling point using the vapor pressure by Moller et al. (2008); second, following Nannoolal et al. (2004, 2008) for both boiling point and vapor pressure; third, following Stein and Brown (1994) for boiling point and vapor pressure by Myrdal and Yalkowsky (1997). Using these three methods, vapor pressures of $7 \times 10^{-17}, 1 \times 10^{-12}$ and $3 \times 10^{-7} \mathrm{~Pa}$, respectively, were obtained for pinyl-diaterpenyl ester at $298 \mathrm{~K}$, and vapor pressures of $4 \times 10^{-15}, 5 \times 10^{-11}$ and $8 \times 10^{-7} \mathrm{~Pa}$, respectively, 
A

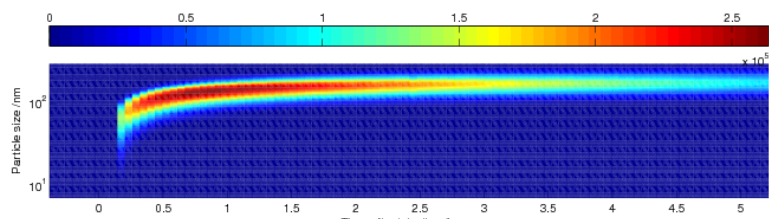

B

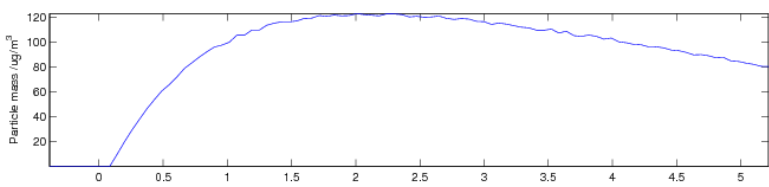

C

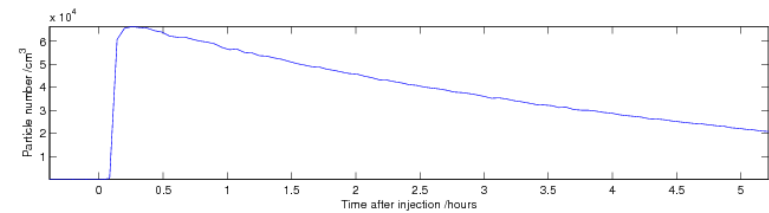

Fig. 2. (A) shows the particle size distribution as a function of time measured with the SMPS system during smog-chamber experiment 2. (B) shows the inferred particle mass and (C) shows the integrated number concentration as a function of time. Similar plots for smogchamber experiments 1, 3 and 4 are provided in the supplementary material.

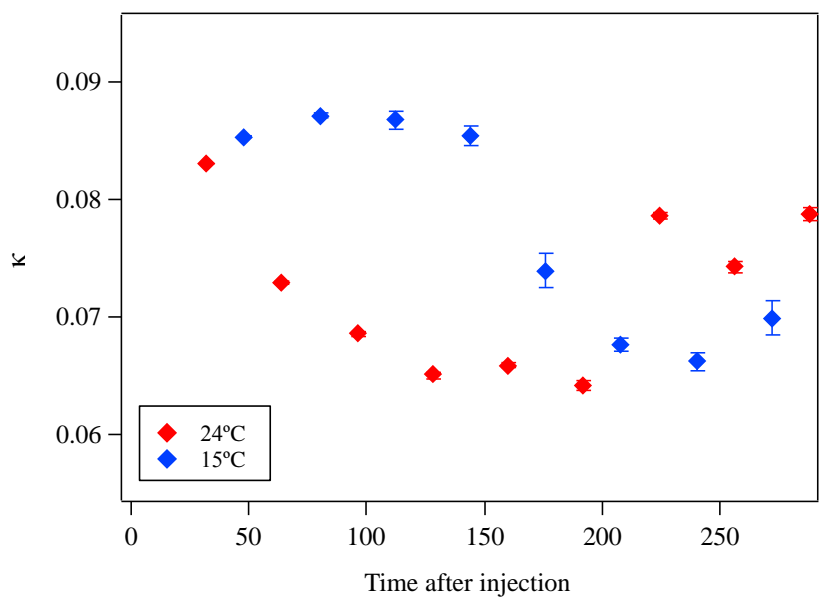

Fig. 3. Time series of the hygroscopicity parameter $\kappa$ calculated from $\mathrm{CCN}$ activation diameters at $0.19 \%$ supersaturation. Error bars are calculated from the error (two standard deviations) obtained from the fitting procedure used to derive activation diameters from the $\mathrm{CCN}$ activation curves.

are obtained for pinonyl-pinyl ester. Recently, Zuend and Seinfeld (2012) estimated the vapor pressure of pinonyl-pinyl ester to $2.5 \times 10^{-11} \mathrm{~Pa}\left(\right.$ at $25^{\circ} \mathrm{C}$ ) using the EVAPORATION model (Compernolle et al., 2011). These estimates differ by orders of magnitude, illustrating the difficulty in estimating vapor pressures of large organic molecules. However, it seems reasonable to expect the vapor pressures of dimer esters to be significantly lower than for pinic acid, making them more likely candidates as nucleating species.
CCN activity of the SOA formed in the chamber is expressed in Fig. 3 in terms of the hygroscopicity parameter $\kappa$ (Petters and Kreidenweis, 2007), which is calculated from the activation diameter measured at $0.19 \%$ supersaturation. All $\kappa$ values are in the range 0.06-0.09. The $\mathrm{CCN}$ activities measured in this study fall within the range of those reported previously (Huff Hartz et al., 2005; VanReken et al., 2005; Prenni et al., 2007).

The difference between $\mathrm{CCN}$ activity of particles formed under cold $\left(15^{\circ} \mathrm{C}\right)$ and warm $\left(24^{\circ} \mathrm{C}\right)$ conditions is very small, with the particles formed at the colder temperature being slightly more CCN active during the first $150-200 \mathrm{~min}$ of the experiments. $\mathrm{CCN}$ activity displays only modest variation during the course of experiments, and there is some indication in Fig. 3 that the rate of the changes depends on chamber temperature. At the higher temperature $\left(24^{\circ} \mathrm{C}\right), \kappa$ decreases (i.e., $\mathrm{CCN}$ activity decreases) by a small but perceptible amount during the first 150-200 min of the experiment, whereas $\mathrm{CCN}$ activity remains relatively constant during this same time period at the lower temperature $\left(15^{\circ} \mathrm{C}\right)$. Following the initial decrease in $\mathrm{CCN}$ activity, there is an increase in the activity under warm conditions, and there is a suggestion of an increase under cold conditions. In summary, the pinyl-diaterpenyl and pinonyl-pinyl esters are indeed formed rapidly in the ozonolysis of $\alpha$-pinene and at concentrations comparable to some first- and second-generation products under both low and warm temperatures in chamber experiments.

\subsection{Field study}

\subsubsection{Pinyl-diaterpenyl ester}

Monoterpene dimer esters were detected in ambient aerosols collected during two field campaigns in the Sierra Nevada Mountains of California (BEARPEX 2007 and 2009). In contrast to the recent study of Yasmeen et al. (2010), the pinyl-diaterpenyl ester (MW 358) of cis-pinic and diaterpenylic acid was observed in all BEARPEX nighttime samples and even in daytime samples during 2009 (Fig. 4). A clear diurnal variation with nighttime maxima was observed during BEARPEX, especially during 2007, when daytime levels were almost negligible. The estimated maximum concentration of the pinyl-diaterpenyl ester was about ten times higher during 2009 compared to 2007 (Table 3). The same tendency was observed for isoprene-derived organosulfates (Worton et al., 2011). The diurnal variation of the pinyldiaterpenyl ester was less pronounced during 2009, and daytime levels grew to ten times the night maxima observed in 2007. The concentration of $\alpha$-pinene ranged from 0.02 $0.1 \mathrm{ppb}$ during the 2007 campaign and $0.05-0.25 \mathrm{ppb}$ during 2009 (Worton et al., 2011; Bouvier-Brown et al., 2009), and the organic aerosol (OA) loading was also somewhat higher in 2009 compared to 2007 (4.3 and $2.1 \mu \mathrm{g} \mathrm{m}^{-3}$, respectively, Worton et al., 2013). Normalization of the dimer ester 

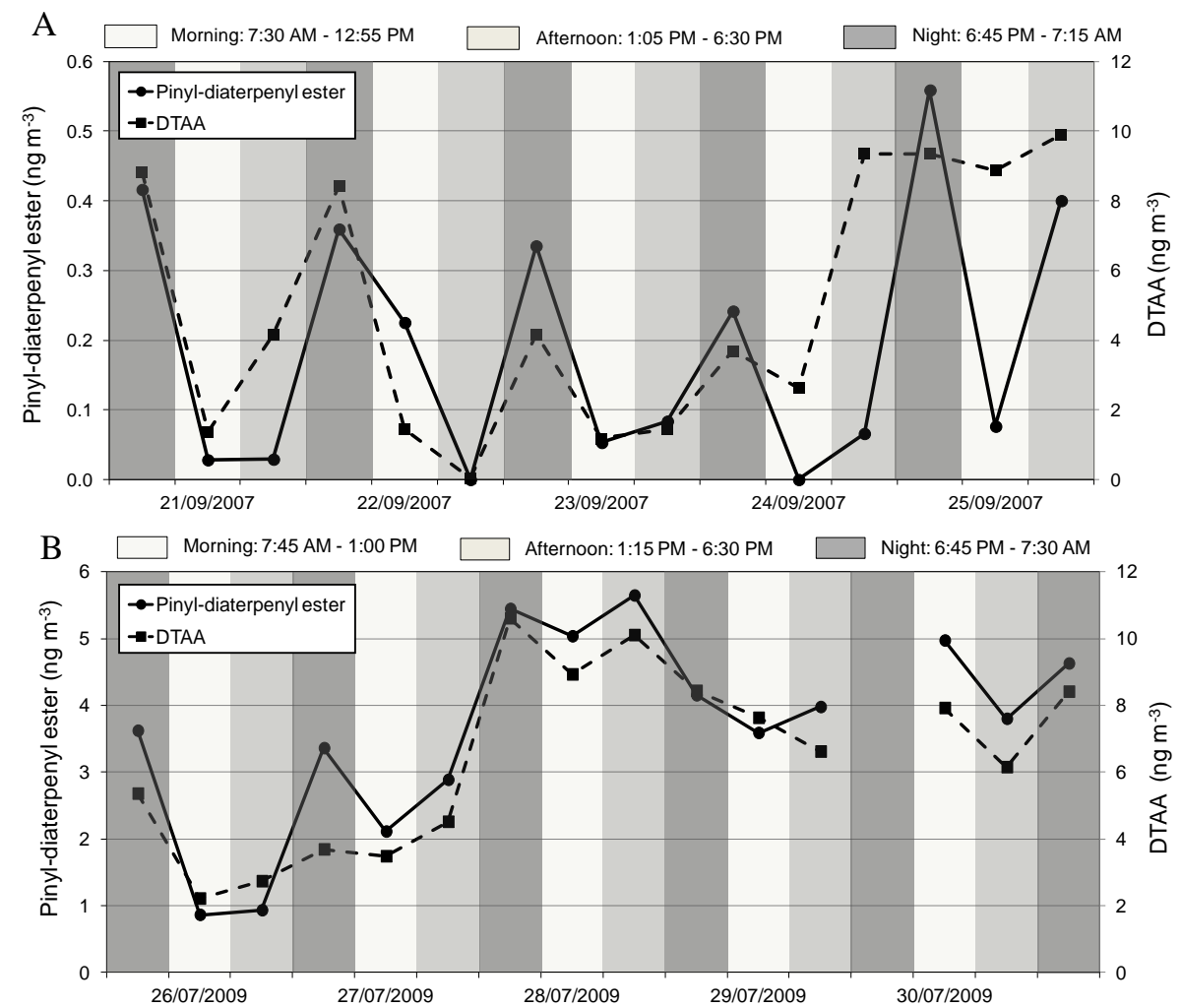

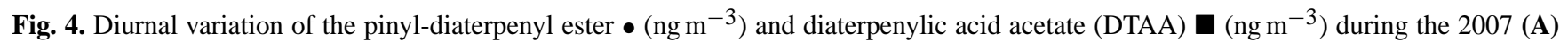
and 2009 (B) campaigns. Note the different scales for pinyl-diaterpenyl ester in (A) and (B). Nighttime samples are highlighted in dark grey.

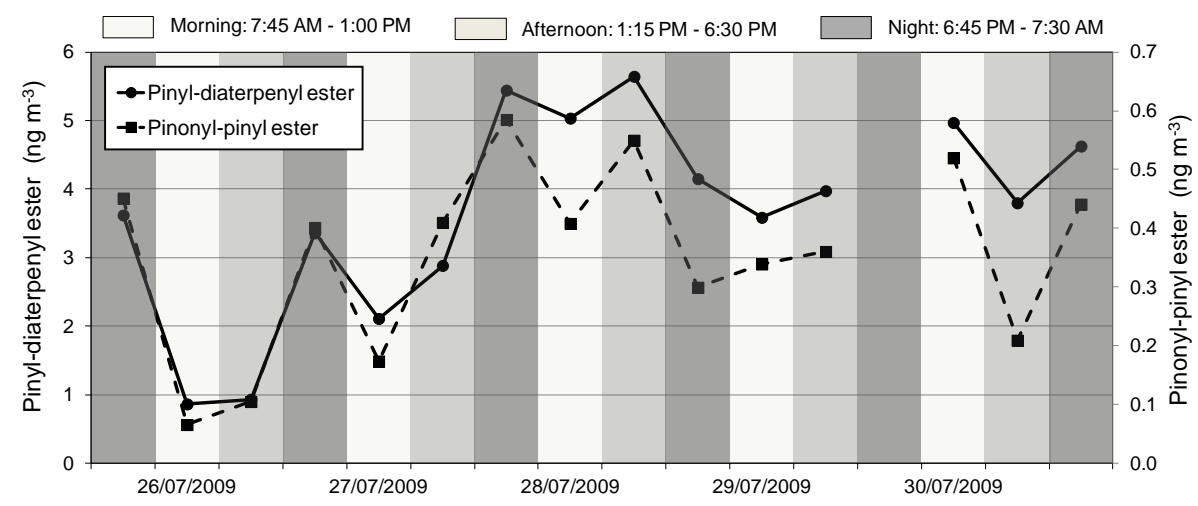

Fig. 5. Diurnal variation of the pinyl-diaterpenyl ester $\bullet\left(\mathrm{ng} \mathrm{m}^{-3}\right)$ and pinonyl-pinyl ester $\mathbf{\square}\left(\mathrm{ng} \mathrm{m}^{-3}\right)$ during the 2009 campaign.

concentrations to OA (Fig. S7) resulted in similar diurnal variation, as shown in Figs. 4 and 5, with a generally higher ester concentration during night compared to daytime samples, indicating that the diurnal changes in the dimer ester concentration are not driven by changes in the boundary layer height.

Scatterplots of the level of pinyl-diaterpenyl ester versus concentrations of the proposed precursors cis-pinic and terpenylic acids showed only some linear correlation ( $R^{2}<0.35, n=30$, data not shown) for both acids, suggesting that the formation of the pinyl-diaterpenyl ester was not controlled by the ambient abundance of either cispinic or terpenylic acid. However, a scatterplot of the pinyldiaterpenyl ester versus the concentration of DTAA during 2009 (Fig. S8) showed a high correlation $\left(R^{2}=0.86, n=\right.$ $15)$, indicating a possible relationship between the formation of the ester and DTAA. In addition to DTAA, the pinyldiaterpenyl ester was also somewhat correlated with diaterpenylic acid ( $R^{2}=0.54, n=15$, Fig. S8), which has been hypothesized to form from the acid-catalyzed hydrolysis of terpenylic acid and DTAA (Yasmeen et al., 2010). During the 2007 campaign, the pinyl-diaterpenyl ester also showed 
the best linear correlation with DTAA and diaterpenylic acid $\left(R^{2}=0.38\right.$ and 0.47 , respectively) of all the analyzed $\alpha$ pinene oxidation products (Fig. S8), though the correlations were much weaker than in 2009.

The correlations between the pinyl-diaterpenyl ester and DTAA in both campaigns and the lack of correlation with terpenylic acid could indicate that the diaterpenylic acid moiety involved in the ester formation is more likely to originate from the acid-catalyzed hydrolysis of DTAA than from terpenylic acid, as previously suggested by Yasmeen et al. (2010). This suggestion is also supported by a higher correlation between diaterpenylic acid and DTAA compared to terpenylic acid, which was observed in both the 2007 and 2009 campaigns. Based on these findings it is reasonable to postulate that the formation of the pinyl-diaterpenyl ester during the BEARPEX campaigns was closely related to the formation of DTAA.

It could be hypothesized that the factor of ten higher abundance of the pinyl-diaterpenyl ester during 2009 was caused by an overall increase in precursor acid concentrations between the September 2007 and July 2009 campaigns. Table 3 shows the average concentrations of the ester and the proposed acid precursors $c i s$-pinic acid, terpenylic acid, DTAA, and diaterpenylic acid. Both cis-pinic acid and DTAA were present at almost similar concentrations during both campaigns (7.6/7.1 and 5.0/6.5 $\mathrm{ng} \mathrm{m}^{-3}$, respectively), while the concentration of terpenylic acid was actually higher in 2007 ( $15.2 \mathrm{ng} \mathrm{m}^{-3}$ in 2007 compared to $8.5 \mathrm{ng} \mathrm{m}^{-3}$ in 2009), possibly due to increased condensation at cooler air temperatures in 2007. Interestingly, the concentration of diaterpenylic acid was somewhat higher in 2009 compared to 2007 (1.2 and $0.6 \mathrm{ng} \mathrm{m}^{-3}$, respectively), which suggests more conversion of DTAA into diaterpenylic acid during the hotter 2009 campaign, although the concentration of DTAA was similar during both campaigns $\left(6.5\right.$ and $\left.5.0 \mathrm{ng} \mathrm{m}^{-3}\right)$. The higher conversion of DTAA into diaterpenylic acid could also be related to the higher aerosol acidity observed in the 2009 campaign (Zhang et al., 2012a). Even though higher temperatures could promote ester formation in the condensed phase, it is still difficult to explain the tenfold increase in maximum concentration of the pinyl-diaterpenyl ester, based on concentrations of the precursor acids. Furthermore, no direct correlation was observed between the abundance of the pinyl-diaterpenyl ester and ambient temperature during either the 2007 or 2009 campaigns $\left(R^{2}=0.12\right.$ and 0.09 , respectively).

\subsubsection{Pinonyl-pinyl ester}

In addition to the pinyl-diaterpenyl ester (MW 358), an ester compound with MW 368 was also observed during the 2009 campaign. This compound was identified, based on its MS-MS fragmentation pattern, as an ester of hydroxypinonic acid and pinic acid. To our knowledge, this is the first reported observation of the pinonyl-pinyl ester in ambient aerosol samples.
In contrast to the pinyl-diaterpenyl ester, the pinonyl-pinyl ester was only observed in aerosol samples from 2009, and, interestingly, abundances of both esters showed similar variations between samples (Fig. 5). The pinonyl-pinyl ester showed a much better linear correlation $\left(R^{2}=0.78, \mathrm{n}=15\right.$, data not shown) with the pinyl-diaterpenyl ester than with its proposed precursors hydroxy-pinonic acid and cis-pinic acid $\left(R^{2}=0.31\right.$ and 0.37 , respectively). This indicated that the concentration of the precursors were not solely responsible for controlling the formation of this ester, similar to the pinyl-diaterpenyl ester. The high correlation between the two observed pinene esters, the pinyl-diaterpenyl ester and the pinonyl-pinyl ester, indicates that other factors besides precursor concentrations are likely more important for governing ester formation and abundances.

\subsubsection{Concentrations of $\alpha$-pinene and its first- and second-generation oxidation products}

During the 2009 campaign the $\alpha$-pinene concentration was considerably higher $(0.05-0.25 \mathrm{ppb})$ compared to the later part of the 2007 campaign when the filters were collected (0.02-0.1 ppb) (Worton et al., 2011; Bouvier-Brown et al., 2009). Consistent with this we observe high concentrations of the first-generation oxidation product pinonic acid in 2009 relative to 2007 (11.0 and $6.1 \mathrm{ng} \mathrm{m}^{-3}$, respectively, Table 3). However, despite the higher concentrations during the 2009 campaign, the $\alpha$-pinene oxidation products $c i s$-pinic acid and DTAA were observed at similar concentrations during both campaigns (Table 3). A suggestion for these lower than expected concentrations of $c i s$-pinic acid and DTAA in 2009 could be a more pronounced conversion of these compounds into esters, such as the pinyl-diaterpenyl and pinonyl-pinyl esters and other oligomers. Assuming that the applied surrogates for the quantification of the dimer esters are valid, concentrations of pinyl-diaterpenyl and pinonyl-pinyl esters range on the order of several $\mathrm{ng} \mathrm{m}^{-3}$ (Table 3 ) and since other yet unidentified esters may also be formed from terpenederived acids like cis-pinic acid, and it is reasonable to hypothesize that ester formation could be a substantial sink of semi-volatile terpene-derived acids.

\subsubsection{Regional transport and photochemical aging}

In the atmosphere the composition and properties of aerosols continually evolve as they are aged through a range of chemical transformations that can occur in the gas and condensed phases. These oxidation reactions have been broadly defined into three categories: fragmentation, functionalization and oligomerization (Jimenez et al., 2009). Oligomerization reactions convert organic monomers in the aerosols into higher MW compounds (Rudich et al., 2007).

During daytime, air masses from Central Valley and Sacramento metropolitan area move upslope and pass the sampling site. At night the flow pattern reverses and aged air masses 

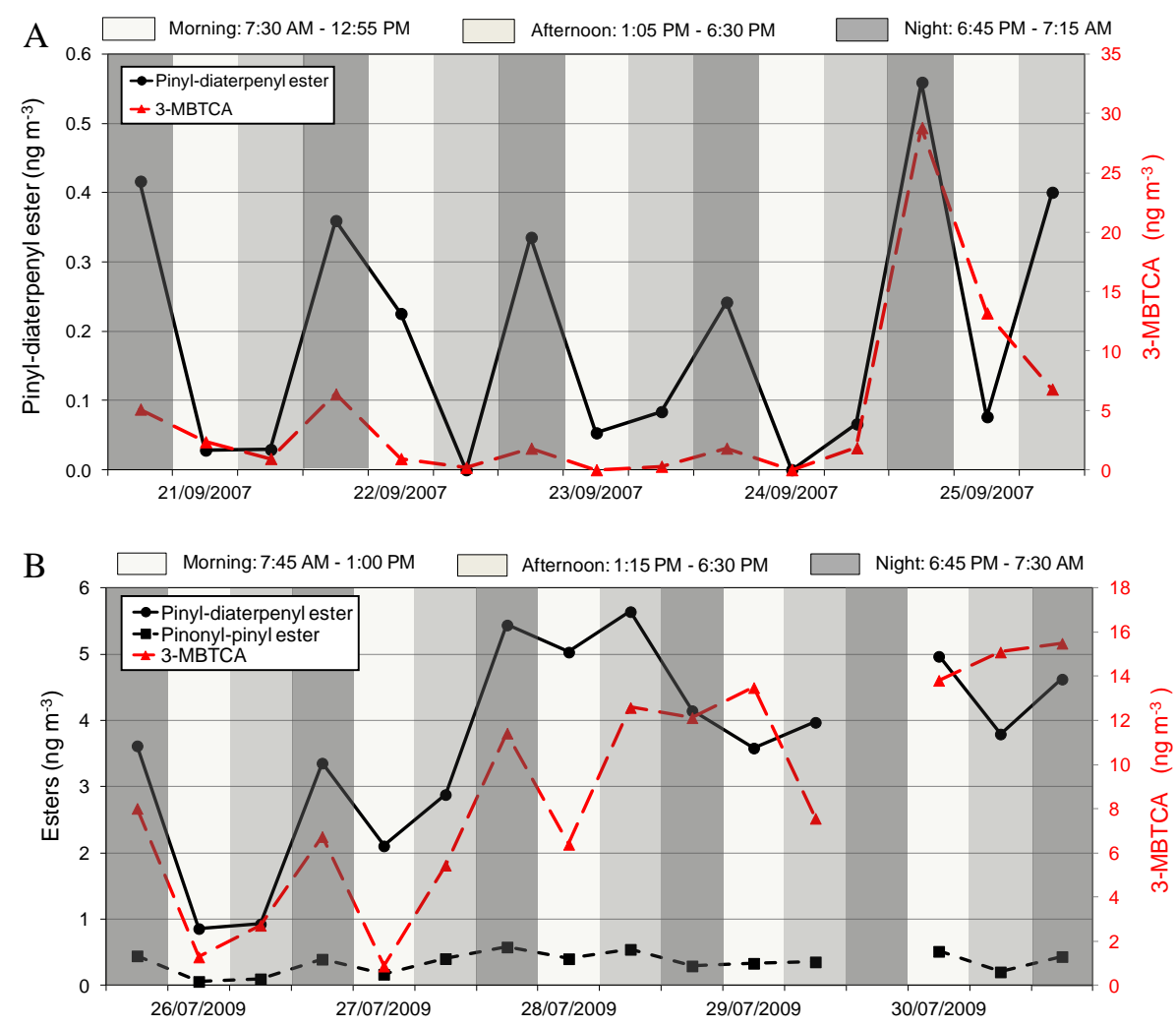

Fig. 6. Diurnal variation of the Pinyl-diaterpenyl ester $\bullet\left(\mathrm{ng} \mathrm{m}^{-3}\right)$, pinonyl-pinyl ester $\mathbf{\square}\left(\mathrm{ng} \mathrm{m}^{-3}\right)$ and 3 -MBTCA $\Delta\left(\right.$ ng $\left.\mathrm{m}^{-3}\right)$ during the 2007 (A) and 2009 campaigns (B) period. Pinonyl-pinyl ester was only observed in 2009.

move back downslope towards the Blodgett forest site (Murphy et al., 2006; Day et al., 2009). Worton et al. (2011) showed how this daily wind pattern affects local diurnal variations in concentrations of both gas- and aerosol-phase organic tracers. Since the Blodgett forest site is affected by $\mathrm{NO}_{\mathrm{x}}$ emissions form the Sacramento area transported uphill during daytime, the aging of locally and regionally emitted BVOC and their reaction products is not well described for this site by the $\mathrm{NO}_{\mathrm{x}} / \mathrm{NO}_{\mathrm{y}}$ or toluene/benzene ratios typically used in photochemical aging studies.

However, since the OH-initiated gas-phase oxidation of pinonic acid has been suggested to be the rate-limiting step in formation of the second generation product 3-methyl-1,2,3butane tricarboxylic acid (MBTCA) (Zhang et al., 2010; Müller et al., 2012), the higher concentration of MBTCA observed in nighttime samples compared to daytime samples (Table 3) could indicate a more photochemically aged air mass at the sampling site during night, in accordance with the meteorological circulation patterns. It should of course be noted that the formation, and hence concentration, of MBTCA, besides the availability of $\mathrm{OH}$ radicals, depends on the gas-phase concentration of pinonic acid and thus factors such as emission and oxidation of $\alpha$-pinene. This could question the usability of MBTCA as an indicator for photochemical aging by $\mathrm{OH}$. However, since the concentration of pinonic acid is highest during daytime and low during night (Table 3 and Fig. S9), the higher MBTCA concentrations observed in nighttime samples are more likely due to the arrival of aged air masses at the sampling site and not due to higher local pinonic acid concentrations. Since the ratio MBTCA/pinonic acid would be affected by temperature-dependent changes in pinonic acid aerosol-phase concentrations (due to evaporation/condensation), we here apply the concentration of MBTCA as a crude measure of $\mathrm{OH}$ oxidation of pinonic acid, and thus photochemical aging of pinenes, although being aware of the above-mentioned factors and uncertainties.

During 2007 some correlation $\left(R^{2}=0.40, n=15\right)$ between the pinyl-diaterpenyl ester and MBTCA was observed with both peaking during nighttime (Fig. 6a). There was a better correlation between MBTCA and the concentration of pinyl-diaterpenyl ester in 2009 campaign $\left(R^{2}=0.57, n=\right.$ 15 ), while the correlation was lower for pinonyl-pinyl ester $\left(R^{2}=0.32, n=15\right)$ (Fig. 6b). The correlations could suggest that the observed dimer esters may not primarily be formed locally, but rather transported to the sampling site through the regular daily meteorological circulation patterns in the region, with aged air masses arriving at the sampling site at night. This is especially evident in the 2007 campaign, where almost no dimer esters were found in the daytime samples despite high concentration of several other $\alpha$-pinene oxidation 
products. However, as shown in Fig. 6, although the highest concentrations of dimer esters are observed at night, the 2009 campaign also shows high dimer concentration in daytime samples. This, along with the observed tenfold increase in the average dimer ester concentration, indicates that other factors besides transport may contribute to the dimer ester concentration during the 2009 campaign. One possible explanation is that the difference in RH between the campaigns affects ester formation. In the 2007 campaign RH was twice as high as in 2009 (Table 3). It was recently suggested that isoprene SOA mass is enhanced at low RH due to particlephase esterification (Nguyen et al., 2011; Zhang et al., 2011, 2012b). If low RH also enhances esterification of pinene oxidation products, this effect could contribute to explaining the observed higher concentrations of dimer esters during the low RH campaign in 2009 compared to 2007. However, no significant correlation was observed between the ester concentrations and RH during either of these campaigns (2007; $R^{2}=0.03,2009 ; R^{2}=0.31$, Fig. S10). In addition, we did not observe a clear correlation between individual esters and acidity (sample average $\mathrm{H}^{+}$concentration from Zhang et al., 2012a).

\section{Conclusions}

In this study we showed that dimer esters of $\alpha$-pinene ozonolysis products were formed in both laboratory chamber oxidation studies and in ambient air in a forested region at both low (about $10-15^{\circ} \mathrm{C}$ ) and high (about $25^{\circ} \mathrm{C}$ ) temperatures. Chamber results show that the dimer esters, such as pinyldiaterpenyl and pinonyl-pinyl esters, were formed within the first $30 \mathrm{~min}$ of the experiment together with first-generation products such as pinonic acid - in contrast to the secondgeneration product MBTCA that forms from $\mathrm{OH}$ oxidation of pinonic acid. Dimer esters may be involved in nucleation due to their estimated lower vapor pressures compared to monomers such as pinic acid. We observed that pinyldiaterpenyl and pinonyl-pinyl esters are indeed formed in $\alpha$ pinene oxidation at concentrations comparable to some firstand second-generation products at both low and warm temperatures in chamber experiments. Future laboratory work is needed to investigate the role of $\mathrm{OH}$-initiated reactions of pinenes as well as the importance of $\mathrm{RH}$ on the formation of these dimer esters.

$\mathrm{CCN}$ activities of the particles formed in the smog chamber displayed a modest variation during the course of experiments. The $\kappa$ values were in the range $0.06-0.09$ (derived at a supersaturation of $0.19 \%$ ), which is consistent with results from other studies reported in the literature.

In ambient air samples from the 2007 and 2009 BEARPEX field campaigns in a forested mountain region in California, two dimer esters (pinyl-diaterpenyl and pinonylpinyl) were observed in daytime aerosol at estimated concentration levels comparable to known first-generation oxi- dation products of $\alpha$-pinene. The pinyl-diaterpenyl ester was observed at even higher concentrations in all nighttime samples. Maximum concentrations were about ten times higher during the warmer 2009 campaign compared to the cooler 2007 campaign. Overall, the analyzed pinene oxidation products made up about $1 \%$ of total organic aerosol mass. While variations in dimer ester concentrations could not be explained by variations in the concentrations of the proposed precursors, the abundances of the pinonyl-pinyl and pinyldiaterpenyl esters were highly correlated, suggesting similar factors besides precursor concentrations were likely responsible for controlling ester formation in the atmosphere. The pinyl-diaterpenyl ester was also correlated with DTAA, suggesting that ester formation may be related to DTAA formation. In accordance with meteorological circulation patterns, a high concentration of MBTCA was observed during night, indicating transport of photochemically aged air masses to the field site. Correlations between the dimer esters and MBTCA during both campaigns suggest that the dimer esters may also be transported to the field site during nighttime. In addition, high concentrations of dimer esters in daytime samples along with a tenfold increase in the average dimer concentration in 2009 compared to 2007 suggest the presence of other factors affecting the formation of dimer esters in 2009.

The observed dimer esters may serve as markers of pinene SOA in future studies of SOA formation and levels.

\section{Supplementary material related to this article is available online at: http://www.atmos-chem-phys.net/13/ 3763/2013/acp-13-3763-2013-supplement.pdf.}

Acknowledgements. We acknowledge the VILLUM FOUNDATION and the European project EUROCHAMP-2 (Integration of European Simulation Chambers for Investigating Atmospheric Processes) within the EC 7th framework programme. We thank Y. Iinuma and O. Böge (Leibniz Institute for Tropospheric Research, Germany) for preparation of standards of terpenylic acid, MBTCA and DTAA. Funding for the BEARPEX campaign was provided by the National Science Foundation (NSF, grant \#0922562) and a University of California Agriculture and Natural Resources (ANR) core issue grant.

Edited by: M. Petters

\section{References}

Andreae, M. O. and Rosenfeld, D.: Aerosol-cloud-precipitation interactions. Part 1. The nature and sources of cloud-active aerosols, Earth Sci. Rev., 89, 13-41, 2008.

Atkinson, R. and Arey, J.: Atmospheric chemistry of biogenic organic compounds, Accounts Chem. Res., 31, 574-583, 1998.

Bench, G. and P. Herckes: Measurement of contemporary and fossil carbon contents of $\mathrm{PM}_{2.5}$ aerosols: Results from Turtleback 
Dome, Yosemite National Park, Environ. Sci Technol., 38, 24242427, 2004.

Bilde, M. and Pandis, S. N.: Evaporation rates and vapor pressures of individual aerosol species formed in the atmospheric oxidation of alpha- and beta- pinene, Environ. Sci Technol., 35, 33443349, 2001.

Bonn, B. and Moortgat, G. K.: Sesquiterpene ozonolysis: Origin of atmospheric new particle formation from biogenic hydrocarbons, Geophys. Res. Lett., 30, 1585, doi:10.1029/2003g1017000, 2003.

Bouvier-Brown, N. C., Goldstein, A. H., Gilman, J. B., Kuster, W. C., and de Gouw, J. A.: In-situ ambient quantification of monoterpenes, sesquiterpenes, and related oxygenated compounds during BEARPEX 2007: implications for gas- and particle-phase chemistry, Atmos. Chem. Phys., 9, 5505-5518, doi:10.5194/acp-9-5505-2009, 2009.

Calogirou, A., Larsen, B. R., and Kotzias, D.: Gas-phase terpene oxidation products: a review, Atmos. Environ., 33, 1423-1439, 1999.

Camredon, M., Hamilton, J. F., Alam, M. S., Wyche, K. P., Carr, T., White, I. R., Monks, P. S., Rickard, A. R., and Bloss, W. J.: Distribution of gaseous and particulate organic composition during dark alpha-pinene ozonolysis, Atmos. Chem. Phys., 10, 28932917, doi:10.5194/acp-10-2893-2010, 2010.

Claeys, M., Iinuma, Y., Szmigielski, R., Surratt, J. D., Blockhuys, F., Van Alsenoy, C., Böge, O., Sierau, B., Gómez-González, Y., Vermeylen, R., Van der Veken, P., Shahgholi, M., Chan, A. W. H., Herrmann, H., Seinfeld, J. H., and Maenhaut, W.: Terpenylic Acid and Related Compounds from the Oxidation of alpha-Pinene: Implications for New Particle Formation and Growth above Forests, Environ. Sci. Technol., 43, 6976-6982, doi:10.1021/es9007596, 2009.

Clegg S. L., Kleeman M. J., Griffin R. J., and Seinfeld J. H.: Effects of uncertainties in the thermodynamic properties of aerosol components in an air quality model - Part 2: Predictions of the vapour pressures of organic compounds Atmos. Chem. Phys., 8, 1087-1103, doi:10.5194/acp-8-1087-2008, 2008.

Compernolle, S., Ceulemans, K., and Müller, J. F.: EVAPORATION: a new vapour pressure estimation method for organic molecules including non-additivity and intramolecular interactions, Atmos. Chem. Phys., 11, 9431-9450, doi:10.5194/acp-119431-2011, 2011.

Day, D. A., D. K. Farmer, A. H. Goldstein, et al.: Observations of NOx, $\Sigma$ PNs, $\Sigma$ ANs, and HNO3 at a Rural Site in the California Sierra Nevada Mountains: summertime diurnal cycles, Atmos. Chem. Phys., 9, 4879-4896, doi:10.5194/acp-9-4879-2009, 2009.

Fry, J. L., Kiendler-Scharr, A., Rollins, A. W., Wooldridge, P. J., Brown, S. S., Fuchs, H., Dubé, W., Mensah, A., dal Maso, M., Tillmann, R., Dorn, H.-P., Brauers, T., and Cohen, R. C.: Organic nitrate and secondary organic aerosol yield from $\mathrm{NO}_{3}$ oxidation of $\beta$-pinene evaluated using a gas-phase kinetics/aerosol partitioning model, Atmos. Chem. Phys., 9, 14311449, doi:10.5194/acp-9-1431-2009, 2009.

Gao, S., Ng, N. L., Keywood, M., Varutbangkul, V., Bahreini, R., Nenes, A., He, J., Yoo, K. Y., Beauchamp, J. L., Hodyss, R. P., Flagan, R. C., and Seinfeld, J. H.: Particle phase acidity and oligomer formation in secondary organic aerosol, Environ. Sci. Technol., 38, 6582-6589, 2004.
Gao, Y., Hall, W. A., and Johnston, M. V.: Molecular Composition of Monoterpene Secondary Organic Aerosol at Low Mass Loading, Environ. Sci. Technol., 44, 7897-7902, doi:10.1021/es101861k, 2010.

Glasius, M., Lahaniati, M., Calogirou, A., Di Bella, D., Jensen, N. R., Hjorth, J., Kotzias, D., and Larsen, B. R.: Carboxylic acids in secondary aerosols from oxidation of cyclic monoterpenes by ozone, Environ. Sci. Technol., 34, 1001-1010, 2000.

Guenther, A., Hewitt, C. N., Erickson, D., Fall, R., Geron, C., Graedel, T., Harley, P., Klinger, L., Lerdau, M., McKay, W. A., Pierce, T., Scholes, B., Steinbrecher, R., Tallamraju, R., Taylor, J., and Zimmerman, P.: A global model of natural volatile organic compound emissions, J. Geophys. Res., 100, 8873-8892, doi:10.1029/94jd02950, 1995.

Hall IV, W. A. and Johnston, M. V.: Oligomer Content of AlphaPinene Secondary Organic Aerosol, Aerosol Sci. Technol., 45, 37-45, doi:10.1080/02786826.2010.517580, 2011.

Hallquist, M., Wenger, J. C., Baltensperger, U., Rudich, Y., Simpson, D., Claeys, M., Dommen, J., Donahue, N. M., George, C., Goldstein, A. H., Hamilton, J. F., Herrmann, H., Hoffmann, T., Iinuma, Y., Jang, M., Jenkin, M. E., Jimenez, J. L., Kiendler-Scharr, A., Maenhaut, W., McFiggans, G., Mentel, Th. F., Monod, A., Prévôt, A. S. H., Seinfeld, J. H., Surratt, J. D., Szmigielski, R., and Wildt, J.: The formation, properties and impact of secondary organic aerosol: current and emerging issues, Atmos. Chem. Phys., 9, 5155-5236, doi:10.5194/acp-9-51552009, 2009.

Heaton, K. J., Dreyfus, M. A., Wang, S., and Johnston, M. V.: Oligomers in the early stage of biogenic secondary organic aerosol formation and growth, Environ. Sci. Technol., 41, 61296136, doi:10.1021/es070314n, 2007.

Huff Hartz, K. E., Rosenoern, T., Ferchak, S. R., Raymond, T. M., Bilde, M., Donahue, N. M., and Pandis, S. N.: Cloud condensation nuclei activation of monoterpene and sesquiterpene secondary organic aerosol, J. Geophys. Res., 110, D14208, doi:10.1029/2004JD005754, 2005.

Iinuma, Y., Muller, C., Berndt, T., Boge, O., Claeys, M., and Herrmann, H.: Evidence for the existence of organosulfates from beta-pinene ozonolysis in ambient secondary organic aerosol, Environ. Sci. Technol., 41, 6678-6683, doi:10.1021/es070938t, 2007.

IPCC: Climate Change 2007 - The Physical Science Basis: Contribution of Working Group I to the Fourth Assessment Report of the IPCC, UK, Cambridge University Press, 2007.

Jimenez, J. L., Canagaratna, M. R., Donahue, N. M., Prevot, A. S. H., Zhang, Q., Kroll, J. H., DeCarlo, P. F., Allan, J. D., Coe, H., Ng, N. L., Aiken, A. C., Docherty, K. S., Ulbrich, I. M., Grieshop, A. P., Robinson, A. L., Duplissy, J., Smith, J. D., Wilson, K. R., Lanz, V. A., Hueglin, C., Sun, Y. L., Tian, J., Laaksonen, A., Raatikainen, T., Rautiainen, J., Vaattovaara, P., Ehn, M., Kulmala, M., Tomlinson, J. M., Collins, D. R., Cubison, M. J., E., Dunlea, J., Huffman, J. A., Onasch, T. B., Alfarra, M. R., Williams, P. I., Bower, K., Kondo, Y., Schneider, J., Drewnick, F., Borrmann, S., Weimer, S., Demerjian, K., Salcedo, D., Cottrell, L., Griffin, R., Takami, A., Miyoshi, T., Hatakeyama, S., Shimono, A., Sun, J. Y., Zhang, Y. M., Dzepina, K., Kimmel, J. R., Sueper, D., Jayne, J. T., Herndon, S. C., Trimborn, A. M., Williams, L. R., Wood, E. C., Middlebrook, A. M., Kolb, C. E., Baltensperger, U., and Worsnop, D. R.: Evolution of Or- 
ganic Aerosols in the Atmosphere, Science, 326, 1525-1529, doi:10.1126/science.1180353, 2009.

Kalberer, M., Paulsen, D., Sax, M., Steinbacher, M., Dommen, J., Prevot, A. S. H., Fisseha, R., Weingartner, E., Frankevich, V., Zenobi, R., and Baltensperger, U.: Identification of polymers as major components of atmospheric organic aerosols, Science, 303, 1659-1662, 2004.

Kiendler-Scharr, A., Wildt, J., Dal Maso, M., Hohaus, T., Kleist, E., Mentel, T. F., Tillmann, R., Uerlings, R., Schurr, U., and Wahner, A.: New particle formation in forests inhibited by isoprene emissions, Nature, 461, 381-384, doi:10.1038/nature08292, 2009.

King, S. M., Butcher, A. C., Rosenoern, T., Coz, E., Lieke, K. I., de Leeuw, G., Nilsson, D. E., and Bilde, M.: Investigating primary marine aerosol properties: $\mathrm{CCN}$ activity of sea salt and mixed inorganic-organic particles, Environ. Sci. Technol., 46, 1040510412, doi:10.1021/es300574u, 2012.

Kristensen, K. and Glasius, M.: Organosulfates and oxidation products from biogenic hydrocarbons in fine aerosols from a forest in North West Europe during spring, Atmos. Environ., 45, 45464556, 2011.

Kroll, J. H. and Seinfeld, J. H.: Chemistry of secondary organic aerosol: Formation and evolution of low-volatility organics in the atmosphere, Atmos. Environ., 42, 3593-3624, doi:10.1016/j.atmosenv.2008.01.003, 2008.

Larsen, B. R., Di Bella, D., Glasius, M., Winterhalter, R., Jensen, N. R., and Hjorth, J.: Gas-phase $\mathrm{OH}$ oxidation of monoterpenes: Gaseous and particulate products, J. Atmos. Chem., 38, 231-276, 2001.

Lohmann, U. and Feichter, J.: Global indirect aerosol effects: a review, Atmos. Chem. Phys., 5, 715-737, doi:10.5194/acp-5-7152005, 2005.

Moller, B., Rarey, J., and Ramjugernath, D.: Estimation of the vapour pressure of non-electrolyte organic compounds via group contributions and group interactions, J. Molec. Liq., 143, 52-63, doi:10.1016/j.molliq.2008.04.020, 2008.

Müller, L., Reinnig, M. C., Warnke, J., and Hoffmann, Th.: Unambiguous identification of esters as oligomers in secondary organic aerosol formed from cyclohexene and cyclohexene/?pinene ozonolysis, Atmos. Chem. Phys., 8, 1423-1433, doi:10.5194/acp-8-1423-2008, 2008.

Müller, L., Reinnig, M.-C., Hayen, H., and Hoffmann, T.: Characterization of oligomeric compounds in secondary organic aerosol using liquid chromatography coupled to electrospray ionization Fourier transform ion cyclotron resonance mass spectrometry, Rapid Commun. Mass Spectrom., 23, 971-979, doi:10.1002/rcm.3957, 2009.

Müller, L., Reinnig, M. C., Naumann, K. H., Saathoff, H., Mentel, T. F., Donahue, N. M., and Hoffmann, T.: Formation of 3-methyl1,2,3-butanetricarboxylic acid via gas phase oxidation of pinonic acid - a mass spectrometric study of SOA aging, Atmos. Chem. Phys., 12, 1483-1496, doi:10.5194/acp-12-1483-2012, 2012.

Murphy, J. G., Day, D. A., Cleary, P. A., Wooldridge, P. J., and Cohen, R. C.: Observations of the diurnal and seasonal trends in nitrogen oxides in the western Sierra Nevada, Atmos. Chem. Phys., 6, 5321-5338, doi:10.5194/acp-6-5321-2006, 2006.

Myrdal, P. B. and Yalkowsky, S. H.: Estimating pure component vapor pressures of complex organic molecules, Industr. Eng. Chem. Res., 36, 2494-2499, doi:10.1021/ie9502421, 1997.
Nannoolal, Y., Rarey, J., Ramjugernath, D., and Cordes, W.: Estimation of pure component properties Part 1. Estimation of the normal boiling point of non-electrolyte organic compounds via group contributions and group interactions, Fluid Phase Equilibria, 226, 45-63, doi:10.1016/j.fluid.2004.09.001, 2004.

Nannoolal, Y., Rarey, J., and Ramjugernath, D.: Estimation of pure component properties - Part 3. Estimation of the vapor pressure of non-electrolyte organic compounds via group contributions and group interactions, Fluid Phase Equil., 269, 117-133, doi:10.1016/j.fluid.2008.04.020, 2008.

Nguyen, T. B., Roach, P. J., Laskin, J., Laskin, A., and Nizkorodov, S. A.: Effect of humidity on the composition of isoprene photooxidation secondary organic aerosol, Atmos. Chem. Phys., 11, 6931-6944, doi:10.5194/acp-11-6931-2011, 2011.

Perraud, V., Bruns, E. A., Ezell, M. J., Johnson, S. N., Greaves, J., and Finlayson-Pitts, B. J.: Identification of Organic Nitrates in the $\mathrm{NO}_{3}$ Radical Initiated Oxidation of $\alpha$-Pinene by Atmospheric Pressure Chemical Ionization Mass Spectrometry, Environ. Sci Technol., 44, 5887-5893, doi:10.1021/es1005658, 2010.

Petters, M. D. and Kreidenweis, S. M.: A single parameter representation of hygroscopic growth and cloud condensation nucleus activity, Atmos. Chem. Phys., 7, 1961-1971, doi:10.5194/acp-71961-2007, 2007.

Petters, M. D., Prenni, A. J., Kreidenweis, S. M., and DeMott, P. J.: On measuring the critical diameter of cloud condensation nuclei using mobility selected aerosol, Aerosol Sci. Technol., 41, 907913, doi:10.1080/02786820701557214, 2007.

Prenni, A. J., Petters, M. D., Kreidenweis, S. M., DeMott, P. J., and Ziemann, P. J.: Cloud droplet activation of secondary organic aerosol, J. Geophys. Res., 112, D10223, doi:10.1029/2006JD007963, 2007.

Putman, A. L., Offenberg, J. H., Fisseha, R., Kundu, S., Rahn, T. A., and Mazzoleni, L. R.: Ultrahigh-resolution FT-ICR mass spectrometry characterization of alphapinene ozonolysis SOA, Atmos. Environ., 46, 164-172, doi:10.1016/j.atmosenv.2011.10.003, 2012.

Rudich, Y., Donahue, N. M., and Mentel, T. F.: Aging of organic aerosol: Bridging the gap between laboratory and field studies, Annu. Rev. Phys. Chem., 58, 321-352, doi:10.1146/annurev.physchem.58.032806.104432, 2007.

Song, C., Zaveri, R. A., Alexander, M. L., Thornton, J. A., Madronich, S., Ortega, J. V., Zelenyuk, A., Yu Xiao-Ying, Laskin, A., and Maughan, D. A.: Effect of hydrophobic primary organic aerosols on secondary organic aerosol formation from ozonolysis of a-pinene, Geophys. Res. Lett., 34, L20803, doi:10.1029/2007GL030720, 2007.

Stein, S. E. and Brown, R. L.: Estimation of normal boiling points from group contributions, J. Chem. Inf. Comput. Sci., 34, 581587, doi:10.1021/ci00019a016, 1994.

Surratt, J. D., Gómez-González, Y., Chan, A. W. H., Vermeylen, R., Shahgholi, M., Kleindienst, T. E., Edney, E. O., Offenberg, J. H., Lewandowski, M., Jaoui, M., Maenhaut, W., Claeys, M., Flagan, R. C., and Seinfeld, J. H.: Organosulfate Formation in Biogenic Secondary Organic Aerosol, J. Phys. Chem. A, 112, 8345-8378, 2008.

Szmigielski, R., Surratt, J. D., Gómez-González, Y., Van der Veken, P., Kourtchev, I., Vermeylen, R., Blockhuys, F., Jaoui, M., Kleindienst, T. E., Lewandowski, M., Offenberg, J. H., Edney, E. O., Seinfeld, J. H., Maenhaut, W., and Claeys, M.: 3-methyl- 
1,2,3-butanetricarboxylic acid: An atmospheric tracer for terpene secondary organic aerosol, Geophys. Res. Lett., 34, L24811, doi:10.1029/2007g1031338, 2007.

Tolocka, M. P., Jang, M., Ginter, J. M., Cox, F. J., Kamens, R. M., and Johnston, M. V.: Formation of oligomers in secondary organic aerosol, Environ. Sci. Technol., 38, 1428-1434, 2004.

VanReken, T. M., Ng, N. L., Flagan, R. C., and Seinfeld, J. H.: Cloud condensation nucleus activation properties of biogenic secondary organic aerosol, J. Geophys. Res., 110, D07206, doi:10.1029/2004JD005465, 2005.

Williams, E. L. and Grosjean, D.: Removal of Atmospheric Oxidants with Annular Denuders, Environ. Sci. Technol., 24, 811$814,1990$.

Worton, D. R., Goldstein, A. H., Farmer, D. K., Docherty, K. S., Jimenez, J. L., Gilman, J. B., Kuster, W. C., de Gouw, J., Williams, B. J., Kreisberg, N. M., Hering, S. V., Bench, G., McKay, M., Kristensen, K., Glasius, M., Surratt, J. D., and Seinfeld, J. H.: Origins and composition of fine atmospheric carbonaceous aerosol in the Sierra Nevada Mountains, California, Atmos. Chem. Phys., 11, 10219-10241, doi:10.5194/acp-1110219-2011, 2011.

Worton, D. R., Surratt, J. D., Lafranchi, B. W., Gilman, J. B., de Gouw, J., Park, C. H., Schade, G., Park, J. H., Beaver, M., Wennberg, P., Wolfe, G., Harrold, S., Thornton, J., Farmer, D. K., Docherty, K. S., Cubison, M. J., Jimenez, J. L., Frossard, A., Russell, L., Kristensen, K., Glasius, M., Covert, D., Mao, J., Ren, X., Brune, W., Chan, A. W. H., Zhao, Y., Weber, R. J., Browne, E., Psuede, S., Cohen, R., Seinfeld, J. H., and Goldstein, A. H.: Observational constraints on high- and low- $\mathrm{NO}_{\mathrm{x}}$ aerosol formation from isoprene, submitted to Environ. Sci. Technol., 2013.

Yasmeen, F., Vermeylen, R., Szmigielski, R., Iinuma, Y., Böge, O., Herrmann, H., Maenhaut, W., and Claeys, M.: Terpenylic acid and related compounds: precursors for dimers in secondary organic aerosol from the ozonolysis of alpha- and beta-pinene, Atmos. Chem. Phys., 10, 9383-9392, doi:10.5194/acp-10-93832010, 2010.
Yu, J. Z., Cocker, D. R., Griffin, R. J., Flagan, R. C., and Seinfeld, J. H.: Gas-phase ozone oxidation of monoterpenes: Gaseous and particulate products, J. Atmos. Chem., 34, 207-258, 1999.

Zhang, Y. Y., Müller, L., Winterhalter, R., Moortgat, G. K., Hoffmann, T., and Pöschl, U.: Seasonal cycle and temperature dependence of pinene oxidation products, dicarboxylic acids and nitrophenols in fine and coarse air particulate matter, Atmos. Chem. Phys., 10, 7859-7873, doi:10.5194/acp-10-7859-2010, 2010.

Zhang, H., Surratt, J. D., Lin, Y.-H., Bapat, J., and Kamens, R. M.: Effect of relative humidity on SOA formation from isoprene/NO photooxidation: enhancement of 2-methylglyceric acid and its corresponding oligoesters under dry conditions, Atmos. Chem. Phys., 11, 6411-6424, doi:10.5194/acp-11-6411-2011, 2011.

Zhang, H., Worton, D. R., Lewandowski, M., Ortega, J., Rubitschun, C. L., Park, J.-H., Kristensen, K., Campuzano-Jost, P., Day, D. A., Jimenez, J. L., Jaoui, M., Offenberg, J. H., Kleindienst, T. E., Gilman, J., Kuster, W. C., de Gouw, J., Park, C., Schade, G. W., Frossard, A. A., Russell, L., Kaser, L., Jud, W., Hansel, A., Cappellin, L., Karl, T., Glasius, M., Guenther, A., Goldstein, A. H., Seinfeld, J. H., Gold, A., Kamens, R. M., and Surratt, J. D.: Organosulfates as Tracers for Secondary Organic Aerosol (SOA) Formation from 2-Methyl-3-Buten-2-ol (MBO) in the Atmosphere, Environ. Sci. Technol., 46, 94379446, doi:10.1021/es301648z, 2012a.

Zhang, H., Lin, Y.-H., Zhang, Z., Zhang, X., Shaw, S. L., Knipping, E. M., Weber, R. J., Gold, A., Kamens, R. M., and Surratt, J. D.: Secondary organic aerosol formation from methacrolein photooxidation: roles of $\mathrm{NO}_{\mathrm{x}}$ level, relative humidity and aerosol acidity, Environ. Chem., doi:10.1071/EN12004, 2012 b.

Zuend, A. and Seinfeld, J. H.: Modeling the gas-particle partitioning of secondary organic aerosol: the importance of liquidliquid phase separation, Atmos. Chem. Phys., 12, 3857-3882, doi:10.5194/acp-12-3857-2012, 2012. 